\title{
Sobre a diabolế na prova pelo éthos na retórica judicial $^{1}$
}

\section{On diabolé in the éthos' proof in judicial rhetoric}

\author{
(6) $10.21680 / 1983-2109.2021 v 28 n 55 I D 19922$ \\ Saulo Bandeira de Oliveira Marques \\ Universidade Federal do Rio Grande do Norte (UFRN) \\ (D) 0000-0003-0943-422X \\ sbmarques@gmail.com
}

\begin{abstract}
Resumo: Para Aristóteles, a prova pelo éthos é a mais eficiente forma de persuasão porque a idoneidade do orador inspira uma maior credibilidade aos seus argumentos. No âmbito da retórica judicial, a tendência do auditório é perceber o éthos do acusador de forma diferente do éthos do acusado. Essa dessimetria tem significativo impacto na receptividade das alegações de um e de outro. A fim de lhe conquistar a confiança, o orador pode recorrer a testemunhos para comprovar o seu bom éthos. Mas, serlhe-ia possível usá-los para infundir suspeitas sobre o caráter (diabolé) de seu adversário? Embora o texto da Retórica aponte para uma resposta afirmativa, leitores de perspectiva de viés moral, a exemplo de Grimaldi, negam essa possibilidade. Nesse sentido, com base nas considerações a respeito da prova pelo éthos na Retórica, pretende-se observar se é possível
\end{abstract}

\footnotetext{
${ }^{1}$ Esse artigo é decorrente de minhas pesquisas realizadas durante o Mestrado em Filosofia no PPGF/UFPB. Sou devedor do apoio e do incentivo do dr. Narbal de Marsillac Fontes, meu orientador, a quem sou bastante grato. Uma versão desse trabalho foi apresentada quando do IV Seminário Rhetor, realizado em João Pessoa, PB, entre os dias 13 e 14 de novembro de 2019. Naquela ocasião, tive a oportunidade de discuti-lo com os participantes que, com suas ponderações e observações, fizeram-me incorporar algumas reflexões para melhor explicar certos pontos. A eles sou grato, em especial ao dr. Marco Valério Classe Colonnelli e à dra. Priscilla Gontijo Leite.
} 
e em até que ponto a diabolé poderia ser utilizada nessa esfera, investigando sua aplicação desde as provas testemunhais.

Palavras-chave: Éthos; Diabolé; Retórica judicial; Provas testemunhais.

\begin{abstract}
For Aristotle, the éthos proof is the most efficient persuasion mode because the speaker's good character gives greater credibility to his arguments. In judicial rhetoric sphere, the dissymmetry between prosecutor and defendant significantly impacts his éthos' perception and, consequently, the receptivity of his claims. In order to acquire his confidence, the rhetor may resort to witnessing to reinforce his good character. But could they be used to arouse suspicion about the character (diabolê) of his opponent? Although the text of Rhetoric points to an affirmative view, moral perspective readers, like Grimaldi, deny this possibility. In this sense, based on considerations about the éthos proof in Rhetoric, it is intended to observe if it is possible and to what extent diabolé could be used in this sphere, investigating its application from the witnesses' proofs.
\end{abstract}

Keywords: Éthos; Diabolê; Judicial rhetoric; Witnesses' proofs.

"Guard yourself against accusations, even if they are false; for the multitude are ignorant of the truth and look only to reputation"

Isócrates, Ad Demonicus, 17

\title{
Considerações iniciais
}

Para Aristóteles, a prova pelo éthos é a mais eficiente forma de persuasão porque a idoneidade do orador propicia uma maior credibilidade para os seus argumentos $(R h .1356 a 5-13) .^{2}$ Em outras

\footnotetext{
${ }^{2}$ A fim de facilitar a consulta em outras traduções, os textos de Aristóteles não serão citados conforme o padrão da ABNT. As citações serão feitas com base na numeração de Bekker em sequência à abreviatura do texto mencionado. Para a Ética a Nicômaco, adotou-se EN.; para a Ética a Eudemo, EE.; para a Retórica, Rh.; para as Refutações Sofísticas, SE.; para os Tópicos, Top.
} 
palavras, o auditório estará mais ou menos receptivo às alegações do orador desde como percebe seu éthos, seja avaliando-o por si, seja comparando-o com o de seu oponente. Sob esse aspecto, mostrar-se idôneo para os ouvintes é o primeiro passo para uma persuasão bem-sucedida, quer para dissuadir ou convencer sobre tal ou tal proposta, quer para censurar ou elogiar certos comportamentos ou ainda para defender-se de ou acusar alguém.

No âmbito da retórica judicial, há uma dessimetria na percepção do auditório sobre o éthos do acusador e do acusado com impacto significativo quanto às alegações de ambos, implicando em creditar uma em detrimento da outra. Contudo, a depender do caso, essa perspectiva inicial pode ser superada ou acentuada caso o orador se mostre mais digno de crédito que o seu adversário. Para tal propósito, Aristóteles sugere como estratégia recorrer à prova testemunhal a fim de corroborar o bom éthos do orador ( $R h$. 1376a24-33) ou denunciar o mau éthos do oponente, mas seria possível utilizá-la para infundir suspeitas sobre o caráter (diabolé) da parte adversa (Rh. 1416a4-1416b15)? Para uma leitura de viés moral da Retórica, como a de Grimaldi $(1980 ; 1988)$, a diabolé é rejeitada; já sob um viés amoral, não se descarta seu uso, desde que sob certos requisitos, a fim de não ingressar em um argumento sofístico (Top. 100a18-101a24).

A fim de verificar se a diabolế é ou não condizente com a prova pelo éthos, em primeiro lugar, apresentam-se algumas noções gerais sobre a prova pelo éthos. Em seguida, examina-se seu uso no gênero retórico judicial, com ênfase nas provas testemunhais. Por fim, discute-se se a diabolế pode ser uma estratégia válida para a prova pelo éthos no âmbito da retórica judicial, desde um contraponto à leitura de moral de Grimaldi.

\section{Breves considerações sobre a prova pelo ếthos}

Aristóteles era um crítico contundente da retórica ensinada pelos rétores (Rh. 1354a12-26). Mais especificamente, sua crítica se dirigia à concepção de retórica que eles sustentavam e reproduziam: 
uma mera "arte" de pleitear (Rh. 1354b25-29; COOPER, 2007, p. 203), cujo foco se concentrava apenas em expedientes de jaez afetivo ou pessoal ( $R h$. 1354a24-26). Em contraposição, o Estagirita alçou a retórica no status de tékhnē, concebendo-a como um modo de raciocinar com vistas a descobrir o argumento mais persuasivo para cada caso ( $R$ h. 1355b26-35).

Assim, segundo Aristóteles, a retórica estaria além das artimanhas discursivas apregoadas pelos rétores, isto é, seria algo mais que um simples manejo de palavras para produzir persuasão: por ser tékhnē, a retórica se organizaria metodologicamente (Top. 101b5-10). Seu método, para o Estagirita, era algo similar a uma demonstração ( $R$ h. 1355a2-14), mas fundado em entimemas desde as provas persuasivas (písteis) ${ }^{3}$ (Rh. 1355b35-1356a4). As písteis ou eram extradiscursivas (inartísticas), quer dizer, existentes antes do e aproveitadas no discurso, a exemplo das leis, dos contratos e dos testemunhos, ou eram intradiscursivas (artísticas), ou seja, criadas (inventio) quando do discurso, tendo por foco ou o próprio orador (prova pelo éthos) ou os seus ouvintes (prova pelo páthos) ou ainda o assunto em questão (prova pelo lógos). ${ }^{4}$

Não obstante tenham o objetivo de tornar um ponto de vista sobre um dubium mais acreditável que outro(s), cada espécie das písteis artísticas o faz sob um viés distinto. Se o orador pretende transformar a confiança que o auditório deposita nele em aquiescência para seus argumentos, ele utilizará a prova pelo éthos.

\footnotetext{
${ }^{3}$ Segundo Grimaldi (1972, p. 53-68; 1980, p. 37-40), o termo pístis (plural, písteis) é empregado em três sentidos distintos na Retórica: a) fonte material de persuasão, b) método persuasivo ou c) convencimento decorrente da persuasão mesma.

${ }^{4}$ Há um debate entre os leitores da Retórica sobre o que seria a prova pelo lógos. Para uma vertente, a prova pelo lógos seria uma operação lógico-discursiva, elaborada a partir do exemplo (parádeigma) e dos entimemas. Para outra, a prova pelo lógos seria aquela voltada para o assunto (prâgma) em discussão, afastandose o máximo das provas pelo éthos e pelo páthos. Essa última perspectiva, para Grimaldi (1972, p. 53-68), parece a interpretação mais adequada, pois o parádeigma e os entimemas são aplicáveis em quaisquer das provas artísticas e não apenas a uma persuasão "lógica", como os adeptos da primeira corrente a consideram (mais a respeito, cf. GRIMALDI, 1980, p. 349-356).
} 
Já se seu objetivo é fazer o auditório anuir a dada proposição de acordo como ela lhe afeta, ele recorrerá à prova pelo páthos. Por fim, caso intente persuadir desde aspectos formais e argumentativos relacionados ao assunto, ele fará uso da prova pelo lógos. Em face do tema sub examine, deixa-se à parte as provas pelo páthos e pelo lógos e prossegue-se com a prova pelo éthos.

Pois bem.

Aquela transformação de confiança em aquiescência operada pela prova pelo éthos mencionada a pouco é possível porque existe uma relação direta entre a receptividade da mensagem e a credibilidade do emissor. Em outros termos, os argumentos são avaliados desde como o auditório enxerga o orador: se seu caráter inspirar suspeita, suas alegações enfrentarão maior resistência; pelo contrário, se se mostrar confiável, elas serão aceitas com mais facilidade. Daí o porquê de o orador se apresentar como alguém idôneo para o seu auditório (DAY, 2007, p. 379-380).

Justamente por o auditório dar crédito mais rápido e firmemente àquele que lhe inspira credibilidade ( $R h$. 1356a6-8), Aristóteles tinha a prova pelo éthos como a mais eficiente entre as písteis $(R h$. 1356a10-13). E, para bem explorar os benefícios dessa correlação, o Estagirita propõe que o orador se mostre como alguém com certas qualidades. Contudo, antes de discorrer sobre esses atributos, convém fazer dois breves esclarecimentos.

O primeiro: a prova pelo éthos não é uma espécie de argumento de autoridade. Ainda que a (boa ou má) "fama" do orador o preceda, o argumento persuasivo não está fundado nela. Quer dizer, não são as credenciais do orador, enquanto alguém experto em algo, só por sua expertise, que farão persuasivos os seus argumentos.

O segundo: embora lhe seja bastante próxima, a prova pelo éthos não é o mesmo que o é a auctoritas na retórica latina. Por auctoritas, os rétores latinos designavam a legitimidade socialmente conferida aos oradores, por sua integridade moral e seu conhecimento, que os qualificavam para emitir uma opinião a respeito de um dado assunto. Assim, a auctoritas é a imagem moral socialmente 
difundida da pessoa do orador na qual o seu discurso encontra, em última instância, um fundamento. Não obstante a idoneidade do orador pretendida pela prova pelo éthos demandar certo reconhecimento social, esse difere daquele da auctoritas por se materializar no discurso e não lhe ser preexistente. Em suma, enquanto na auctoritas o caráter do orador já está consumado, na prova pelo éthos ele está em construção.

Isso não significa que a "primeira impressão" sobre o orador não tenha qualquer impacto na maneira pela qual o auditório inicialmente vai considerar seus argumentos. As opiniões preexistentes, sejam ou não positivas a seu respeito, serão o ponto a partir do qual o orador deve ponderar para se mostrar uma pessoa idônea ao seu auditório, construindo sua credibilidade, quando de sua fala, desde os valores que o seu público julga como qualidades (Rh. 1404a1-13). Nesse sentido, o orador destacará determinado aspecto de seu caráter e apor-lhe-á um valor ( $R$ h. 1367a32-1367b7) que esteja de acordo com as concepções dos seus ouvintes ( $R h$. 1367b8-11).

Para tanto, como se poderia supor, convém ao orador conhecer o seu auditório. Ainda enquanto uma continuação de sua análise das páthē na prova pelo páthos, Aristóteles elenca algumas características gerais, com base na faixa etária e nas condições sociais, que servem de apoio para uma noção prévia a respeito de possíveis públicos e, mesmo de modo incipiente, orientar o orador quanto ao modo de se portar e ao que deles esperar. Por exemplo, se os seus ouvintes forem idosos, é preciso estar preparado para enfrentar seu pessimismo e sua desconfiança ( $R h$. 1389b19-24) ou, se forem emergentes ("novos ricos", neoploutos), estar ciente de sua soberba e imoderação no agir ( $R h$. 1391a14-19). Desde esses quadros generalistas, o orador tem um ponto de partida para superar as barreiras da primeira impressão e, assim, em uma contínua autoavaliação, cujo foco está no modo como o seu público se manifesta, moldar o seu éthos, adaptando-o de acordo com a cosmovisão de seus ouvintes (COOPER, 2007, p. 206-207). 
Perceba-se a intenção do orador, por meio da prova pelo éthos, de se inserir no âmbito social de seu auditório, construindo uma imagem de si como alguém cuja índole espelhe os valores que aquele público tem por positivos (DAY, 2007, p. 379-380). Assim feito, mostrando-se uma pessoa portadora de tais e tais qualidades, o orador torna-se alguém confiável e, então, com base nessa confiança recebida, suas proposições encontram acolhida entre os seus ouvintes, que as consentem (SATTLER, 1947, p. 55-56). Segundo Aristóteles, para transparecer um éthos desse jaez, bastava ao orador se mostrar sensato, virtuoso e benevolente ( $R h$. 1378a6-9).

Essa relação é exaustiva ( $R$ h. 1378a14-15) e foi elaborada com base na percepção de auditórios sobre tipos de comportamento de oradores que dão azo à suspeita e, consequentemente, à perda de credibilidade ( $R h .1378$ a9-14). Ainda que aparentem um viés moral - e fomentem, por isso, leituras orientadas desde esse ponto de vista, mais adiante comentadas -, essas qualidades nem decorrem de uma disposição axiológica íntima do orador, nem têm conteúdo definido. A ele é bastante parecer (phaneîen) sensato, virtuoso e benevolente; não precisa sê-lo ( $R h$. 1378a15-20).

Nesse sentido, dentre e a partir das opiniões comuns "a todos, à maioria ou aos mais sábios e, dentre esses, de todos, da maioria ou dos mais eminentes" (Top. 100b21-23) que compõe o seu auditório a respeito de tais qualificações, o orador encontrará aquela perspectiva mais próxima ao seu caráter, manejando-a a fim de fazêlos análogos. Assim, por exemplo, pode mostrar-se simples se, para seu auditório, a simplicidade for um sinal de honestidade ou, se for impolido, fazer com que sua impolidez seja percebida como um gesto de sinceridade ( $R$ h. 1367a32-1367b7). Perceba-se a fluidez que "sensatez", "virtude" e "benevolência" podem assumir quando do discurso persuasivo.

Alguns intérpretes, no entanto, procuram estabelecer um vínculo entre a moral e a prática da retórica, lendo a Retórica desde as Éticas aristotélicas. Sattler (1947, p. 57-61), por exemplo, entende que a 
"doutrina da escolha"5 é a chave de leitura correta para compreender a prova pelo éthos. Grimaldi (1988, p. 9-12), por seu turno, elenca uma série de argumentos, com foco, especialmente, no modelo de bom orador, em sentido moral, delineado pela tradição - Tucídides, Platão, Cícero, Plutarco, etc. -, fazendo-o semelhante à figura do "homem de virtude" ${ }^{6}$ do Estagirita. Contudo, antes de abordar com mais detalhes as leituras de viés moral, é preciso fazer algumas considerações sobre o uso da prova pelo éthos na retórica judicial. É do que se trata na próxima seção.

\section{A prova pelo éthos na retórica judicial}

Para Aristóteles, o discurso retórico tinha três propósitos básicos: a) aconselhar ou dissuadir; b) acusar ou defender-se; e c) elogiar ou censurar ( $R h$. 1358b6-13). ${ }^{7}$ Mesmo distintos e inconfundíveis entre si, esses escopos retóricos não eram estanques, sendo possível ao rétor, em dada circunstância, lançar mão de quaisquer deles, até de todos os três, inclusive, para persuadir sobre certo aspecto de um dubium (Rh. 1358b20-29), a exemplo da prática retórica no âmbito dos tribunais. Para o Estagirita, o discurso do gênero judicial gravitava em redor da acusação e da defesa, mas, complementar e acidentalmente, poderia enveredar por outros vieses (dissuadir, censurar, etc.), a depender do caso. No entanto, o rétor não deveria

${ }^{5}$ Como explica Hutchinson (1999, p. 208-210), para Aristóteles, o caráter do sujeito se revela quando da prática das ações voluntárias, pois as escolhas são feitas tendo por meta um dado propósito (EN. 1113b3-7; EE. 1226b5-20). Nesse sentido, as escolhas revelam o fim pretendido e o fim demonstra o seu éthos (EN. 1105a171105b18; EE. 1228a2-15). É a essa relação que Sattler se refere como "doutrina da escolha".

${ }^{6} \mathrm{O}$ "homem de virtude" ao qual Grimaldi alude é a figura do phrónimos, aquele que vive bem e é, portanto, medida e modelo para uma vida moral concreta (EN. 1099a21-24; 1113a25-1113b2; 1176a8-29; e 1140a24-1140b30).

${ }^{7} \mathrm{~A}$ cada um desses propósitos, há um gênero de discurso retórico respectivo: para o conselho e a dissuasão, o deliberativo; para o elogio e a censura, o epidíctico; e para a acusação e a defesa, o judicial. Pela característica dos temas envolvidos, o discurso deliberativo trata de eventos futuros; o epidíctico, de situações presentes; e o judicial, de acontecimentos passados. 
se desviar do ponto principal discutido naquele litígio, um expediente muito comum e severamente criticado por Aristóteles (Rh. 1354a11-1354b22).

O foco da retórica judicial deveria apontar para o justo e o injusto, desenvolvendo uma argumentação apta para atribuir esse ou aquele valor para o caso sob julgamento e não produzir um discurso para sensibilizar os julgadores ( $R h$. 1354a16-18), algo estéril e inútil nos lugares onde se proibia tratar de assuntos alheios à questão da lide ( $R$ h. 1354a18-21). Ainda que seja possível traçar um paralelo entre as exposições da Retórica e da Ética a Nicômaco, a justiça é tratada naquela de forma instrumental, quer dizer, desde uma perspectiva auxiliar à tarefa de persuadir (Rh. 1368b1-6 e 1368b28-33). Nesse sentido, Aristóteles discute a justiça e a injustiça desde seus critérios e/ou parâmetros de definição, suas causas e seus agentes, bem como o uso das provas inartísticas. De modo geral, o Estagirita examina como e quais estratégias podem ser utilizadas, quer pelo acusador, quer pelo acusado, para caracterizar um ato como justo ou injusto de acordo com a visão de Mundo dos julgadores ( $R h$. 1368b6-27). E, nesse âmbito, a prova pelo éthos ganha relevo.

Embora Aristóteles considere a prova pelo éthos mais adequada ao gênero deliberativo e a prova pelo páthos a mais condizente ao gênero judicial ( $R h$. 1377b25-31), há casos nos quais a lide será decidida em favor da parte que mostrar um caráter consentâneo com a concepção de idoneidade aceita entre os juízes. E o motivo para tanto parece bastante intuitivo: como anota Fortenbaugh (2006, p. 323), a visão comum é que "pessoas de bem" não cometem crimes - ou fazem falsas acusações. Assim sendo, quer para superar, quer para reforçar aquela suposição inicial sobre o seu caráter, é conveniente que o orador demonstre um éthos reputado idôneo, seja por si mesmo, seja em contraposição ao de seu adversário.

Para tal propósito, Aristóteles sugere como estratégia recorrer ao depoimento de testemunhas ( $R$ h. 1376a24-33). Tratando da prova testemunhal no âmbito da retórica judicial, Aristóteles menciona dois tipos de testemunhos: os antigos, citações de poetas e pessoas 
ilustres do passado cuja fama perpassa os tempos ( $R h$. 1375b26-29), e os recentes, declarações de pessoas ilustres ( $R h$. 1376a7-9), mas ainda não afamadas. Dentre esses, há as testemunhas judiciais, aquelas que participam do processo e, por isso, também podem ser processadas, e as que estão fora da lide e podem atestar a qualidade das ações (justa, injusta, etc.) (Rh. 1376a12-17). Os testemunhos podem referir-se ao próprio orador ou ao seu oponente ou ainda às suas testemunhas, à causa mesma ou a fatos a ela conexos, como também servir para o orador comprovar seu bom éthos ou provar o mau éthos da parte adversa ou de suas testemunhas ( $R h$. 1376a2433).

Esse último aspecto faz da prova testemunhal uma aliada ímpar na prova pelo éthos na retórica judicial.

Como se tem recorrentemente apontado ao longo dessas páginas, o modo pelo qual o auditório recebe os argumentos do orador está diretamente relacionado à forma pela qual ele percebe o seu éthos e, no âmbito da retórica judicial, isso não é diferente. Em sua atividade judicante, que não é isenta de preconceitos, afinidades, intolerâncias e compaixão (COOPER, 2007, p. 207), os julgadores tendem a ver o acusador e o acusado sob perspectivas distintas. E, em um cenário desse tipo, é primordial ao orador se mostrar uma pessoa idônea.

Conforme mencionado um pouco mais acima, os testemunhos ora são utilizados para comprovar o bom éthos do orador, ora para provar o mau éthos do oponente. Como bem o parece, a intenção nesse último caso é desacreditar o adversário, criando maior resistência aos seus argumentos. Nesse sentido, se depoimentos contrários ao acusador lhe fizerem transparecer uma imagem de alguém de má índole, suas alegações serão vistas enquanto falsas acusações; se para o acusado lhe apresentarem uma imagem de mau caráter, os juízes enxergá-lo-ão como alguém capaz de praticar injustiças (FORTENBAUGH, 2006, p. 324, nota n. 18).

Ainda em relação à persuasão pelo éthos na retórica judicial, mas não apenas nesse âmbito, há outra forma de desacreditar o 
oponente: a diabolê. Conforme assinalam Liddell e Scott (1996, p. 390) em seu Lexicon, por "diabolé" normalmente os autores estão a denotar uma falsa acusação, uma injúria, uma calúnia, a insinuar algo malicioso ou falso, a provocar suspeitas sobre o caráter de alguém, etc. Aristóteles trata do tema desde uma perspectiva técnica, contudo não menos inescrupulosa ( $R h$. 1416a4-1416b15).

A diabolé, na Retórica, assume um sentido técnico algo como criar ou refutar insinuações, maliciosamente ou não, mas sempre de forma intencional, que façam transparecer uma falha no caráter da outra parte. Essa estratégia de apontar ou defender-se de uma suspeição do éthos pode ser levada a efeito através de doze modos, dos quais nove têm uma disposição mais defensiva e três, mais ofensiva. $^{8}$ No que concerne à exposição desse texto, a atenção se concentrará em um dos vieses ofensivos, o da insinuação pelos signos (Rh. 1416a36-1416b3).

Resumidamente, por esse tópos, quer o acusador, quer o acusado, através de certos indícios de relação entre comportamentos, laços afetivos ou familiares, eventos, situações, circunstâncias, etc., procura insinuar uma falha no caráter do oponente. O exemplo oferecido por Aristóteles é significativo: Odisseu insinua a culpabilidade de Teucro na morte de Ajax apontando seu grau de parentesco com a família real de Troia. ${ }^{9}$ Ao

${ }^{8}$ Os tópoi listados por Aristóteles são: a) refutar suposição capciosa ( $R h$. 1416a46); b) negar a imputação ( $R h$. 1416a6-13); c) alegar involuntariedade ( $R h$. 1416a13-20); d) apelar à hipocrisia ( $R$ h. 1416a20-21); e) generalizar indevidamente (Rh. 1416a21-24); f) "envenenar o poço" (Rh. 1416a24-26); g) acusar o acusador ( $R$ h. 1416a26-28); h) apontar um "red herring" (Rh. 1416a28$34)$; i) reverter a acusação ( $R$ h. 1416a34-36); j) fazer insinuações por signos ( $R h$. 1416a36-1416b3); k) confundir os valores (Rh. 1416b4-8); l) buscar uma causa conveniente ( $R$ h. 1416b8-15).

9 Teucro era filho de Hesíone, irmã de Príamo, rei de Troia, e de Telamón, o que o fazia irmão unilateral de Ajax por parte de pai. Após a morte de Aquiles, sua armadura foi posta à disposição dos que se julgassem merecedores. Odisseu e Ajax a requereram e, por decisão de Agamemnon e Menelau, ela foi entregue a Odisseu. Furioso, Ajax decidiu vingar-se daqueles, mas, por intervenção de Atenas, sofreu uma alucinação e, em seu delírio, dizimou um rebanho de ovelhas imaginando tratar-se de um exército. Voltando a si e vendo o que fizera, ficou profundamente 
aduzir tal pertença familiar, Odisseu intenta atribuir um éthos vingativo a Teucro, sugerindo que a sua omissão foi dolosa, e, assim, impregnar seus argumentos de suspeita - talvez, fazendo os juízes tomá-los como pura desfaçatez.

A intenção é implicar no sujeito ou no evento do Mundo, a partir de uma de suas características, um valor negativo. Essa modalidade de diabolé é bastante eficiente porque faz o auditório considerar os próprios aspectos apresentados, seja pelo agente, seja pela ação ou de suas consequências, como alguém ou algo de jaez reprovável. E, nesse caso, a prova testemunhal serve de elo entre a insinuação e aquela característica fenomenal escolhida, à maneira de um signo. ${ }^{10-}$ 11

Assim, através dos relatos certos, o auditório se veria "forçado" a estabelecer uma conexão entre tais ou tais aspectos e as insinuações do orador, ratificando-as desde o seu ponto de vista. Por exemplo, em um processo de antídose, ${ }^{12}$ a fim de imputar o maior patrimônio

envergonhado e cometeu suicídio. Embora Teucro tenha enfrentado Agamemnon para garantir ao seu irmão as honras fúnebres, Telamón considerou sua decisão de não vingar Ajax desonrosa e desterrou-o.

${ }^{10}$ Em Analíticos Anteriores 70a6-10, Aristóteles define signo como uma proposição demonstrativa, necessária ou plausível, que implica que algo, anterior ou posterior a outro algo, é um sinal da produção ou da existência desse algo.

${ }^{11} \mathrm{Na}$ Retórica, Aristóteles apresenta dois tipos de signo: o não-concludente, sem um nome específico, que, embora estabeleça uma relação entre eventos, é passível de refutação, a exemplo de "Sócrates é justo, Sócrates é sábio, logo todo sábio é justo" (nem todos os sábios são justos, infelizmente...) (adaptado de Retórica, 1357b10-14); e o concludente, que resulta em uma relação "necessária", "concludente" (tekmếrion), como, por exemplo, em "toda lactante deu à luz, essa mulher é lactante, então essa mulher deu à luz" (adaptado de Retórica, 1357b1417). Mais sobre os signos na Retórica, cf. Grimaldi (1972, p. 104-135; 1980, p. 6366).

${ }^{12} \mathrm{Na}$ antiga Atenas, os cidadãos mais ricos eram nomeados para financiar as diversas liturgias públicas. Entretanto, aquele indicado para um desses encargos poderia dele declinar se apontasse outro cidadão que fosse mais rico. Caso o indicado concordasse que era mais rico, assumia a tarefa; caso discordasse, quem o apontou poderia mover um processo para permutar seus patrimônios (antídosis) e, uma vez realizada a troca, o agora proprietário da maior fortuna custearia a cerimônia que the fora incumbida (LIDDELL; SCOTT, 1996, p. 155). 
entre ambos ao requerido, o requerente pode caracterizá-lo como alguém extravagante (dapanērós) e apresentar testemunhas que confirmem essa característica (EN. 1123a19-33). Em sua defesa, o requerido pode alegar que o real motivo do processo não é a impossibilidade de o requerente cumprir suas obrigações litúrgicas, afinal, seus bens são de igual vulto, mas a inveja que sente dele, fazendo-o alguém ávido de ter o seu patrimônio, não pelo valor econômico, e, sim, só por ele, o requerido, ser o dono ( $R$ h. 1388a1625), "provando" essa diabolé com relatos de testemunhas.

Como já se deve ter percebido, o uso da diabolế enquanto um meio persuasivo vai de encontro àquilo preconizado pelas leituras de viés moral, entre as quais a de Grimaldi é um exemplo significativo. Essa divergência interpretativa será o tema abordado na próxima seção.

\section{Moral, prova pelo êthos e diabolé}

As leituras de viés moral da Retórica têm bases interpretativas distintas. Algumas, a exemplo da de Sattler, procuram fundamentarse em uma leitura conjunta da Retórica com as Éticas (nicomaquéia e eudêmia) e a Política; outras procuram estabelecer seu ponto de vista desde a Retórica mesma, recorrendo a trechos nos quais Aristóteles exorta os rétores a praticarem a retórica de forma justa. ${ }^{13}$ Grimaldi é um exemplo de leitor desse viés interpretativo, apoiandose em dois trechos da Retórica: $1354 \mathrm{a} 1^{14}$ e $1355 \mathrm{~b} 15-21^{15}$.

\footnotetext{
${ }^{13}$ Entre outros, Retórica, 1354a24-26, 1355a23-24, 1355a29-35 e 1355b2-7.

14 "Rhetoric is the counterpart of dialectic".

15 "Furthermore, it is plain that it is the function of one and the same art to discern the real and the apparent means of persuasion, just as it is the function of dialectic to discern the real and the apparent syllogism. What makes a man a 'sophist' is not his faculty, but his moral purpose. In rhetoric, however, the term 'rhetorician' may describe either the speaker's knowledge of the art, or his moral purpose. In dialectic it is different: a man is a 'sophist' because he has a certain kind of moral purpose, a 'dialectician' in respect, not of his moral purpose, but of his faculty".
} 
Resumidamente, para Grimaldi, a retórica aristotélica tem um jaez marcadamente moral por ser uma antístrofe ${ }^{16}$ da dialética. Há, assim, um paralelo entre retórica, dialética e sofística: a sofística estaria para a retórica do mesmo modo que estaria para a dialética. ${ }^{17}$ Enquanto antístrofe, não haveria uma retórica imoral porque a "má" retórica não é retórica, mas, sim, sofística (GRIMALDI, 1980, p. 3334).

Para manter-se coerente em sua leitura, Grimaldi ora acentua uma interpretação de viés moral de um trecho (como em $R h$. 1355a20-35), ora ou rejeita (a exemplo de $R h$. 1355b17-21) ou mesmo se omite (por exemplo em $R h$. 1359b8-12) se tal trecho apresentar uma perspectiva ambivalente quanto ao aspecto moral da Retórica.

\footnotetext{
${ }^{16}$ Ainda que exija um tratamento mais detido, algo que estaria além dos limites desse texto, convém fazer algumas breves observações sobre a relação "antistrófica" entre a retórica e a dialética. Denotativamente, a antístrofe é um movimento do coral em sentido oposto ao da estrofe (BRUNSCHWIG, 1996, p. 34-35; LIDDELL; SCOTT, 1996, p. 163-164). No Górgias, Platão a toma enquanto uma metáfora para desqualificar a retórica, comparando-a de forma pejorativa à arte culinária. Aristóteles resgata essa metáfora da antístrofe e compara a retórica à dialética, algo que "estremeceria os muros da Academia" (BRUNSCHWIG, 1996, p. 34). Como antístrofe da dialética, a retórica lhe seria próxima, mas não idêntica, por seguir um caminho "oposto". O Estagirita mesmo faz um paralelo entre a retórica e a dialética, como se pode perceber nos Tópicos 101a25-101b4 e na Retórica 1355a19-38. Há uma série de leituras sobre a pretensão de Aristóteles nessa comparação, cujo debate ainda está em aberto. Para Brunschwig (1996, p. 38), por exemplo, tal proximidade entre uma e outra seria uma indicação de que a Retórica deveria ser lida desde os Tópicos, sem, contudo, ignorar as Refutações Sofísticas. Mais sobre o tema, cf. Brunschwig (1996).

${ }^{17}$ Metafísica, 1004b17-24: "[...] dialecticians and sophists assume the same guise as the philosopher, for sophistic is philosophy which exists only in semblance, and dialecticians embrace all things in their dialectic, and being is common to all things; but evidently their dialectic embraces these subjects because these are proper to philosophy. For sophistic and dialectic turn on the same class of things as philosophy, but this differs from dialectic in the nature of the faculty required and from sophistic in respect of the purpose of the philosophic life. Dialectic is merely critical where philosophy claims to know, and sophistic is what appears to be philosophy but is not".
}

Comparar esse trecho com a citação na nota anterior. 
Em relação à prova pelo êthos, Grimaldi (1980, p. 41-42) lê Retórica 1356a5-13 enfatizando o sentido positivo do éthos, tomando-o enquanto sinônimo de caráter justo, honesto ou razoável desde o termo epieikés ${ }^{18}$ ( $R$ h. 1356a6). Essa leitura encontraria respaldo nos requisitos que qualificam um bom orador elencados por Aristóteles em Retórica 1378a6-20 - sensatez, virtude e benevolência. Em seus comentários a esse trecho, Grimaldi (1988, p. 9-12) destaca o sentido moral desses três atributos quando da persuasão retórica: sensatez (phrónesis) e virtude (aretế) para deliberar bem, isto é, fazer boas escolhas moralmente falando, e benevolência (eúnoia) para fazê-lo de boa-fé, com vistas ao bem.

Contudo, ainda quanto aos atributos do rétor, Aristóteles remete à "análise das virtudes" (Rh. 1378a16-19), no Livro I da Retórica, para caracterizar aquelas três qualidades. Ali, há um trecho $(R h$. 1367a32-1367b11) que coloca a interpretação de Grimaldi em xeque. Mesmo en passant, no final da primeira seção, aludiu-se àquela passagem para exemplificar o quanto sensatez, virtude e benevolência poderiam circunstancialmente assumir sentidos distintos. Grimaldi (1980, p. 207-211) procura lê-la sob uma perspectiva moral, alegando uma má-compreensão das leituras que a interpretam sob um viés instrumental - algo incoerente com a filosofia do Estagirita por lhe atribuir uma defesa da sofística ao rejeitar a verdade quando propõe que se delibere no âmbito da falsidade (GRIMALDI, 1980, p. 208).

Essa perspectiva moral de Grimaldi impõe um sentido bastante limitado ao auxílio da prova testemunhal enquanto um recurso da prova pelo éthos em Retórica 1376a24-33. Nesse trecho, Aristóteles aconselha ter sempre um testemunho, se não para comprovar como os fatos se deram, para corroborar com o bom éthos do orador (e/ou de suas testemunhas) ou apontar o mau éthos do adversário (e/ou de suas testemunhas). Se a leitura de Grimaldi (1980, p. 332-333) estiver correta, esse último caso só seria utilizado se realmente

${ }^{18}$ De epieíkeia. Consoante Liddell e Scott (1996, p. 632), quando se refere a pessoas, epieíkeia pode significar que alguém é justo, razoável, benevolente ou clemente. 
houvesse um mau éthos. Mas, na prática, não era bem assim que acontecia...

O ponto de vista do Estagirita sobre a retórica, apresentado logo na abertura da primeira seção, é de ela ser uma tékhnē, quer dizer, um conjunto de regras para produzir algo ou para manejá-lo da maneira correta, sem qualquer viés moral (Rh. 1355b26-35) - talvez por isso Aristóteles exorte para que se pratique a retórica de forma "justa" (Rh. 1355b2-7). E um exemplo significativo de sua instrumentalidade está no uso das provas não-técnicas no âmbito da retórica judicial.

Em Retórica 1375a22-1377b12, o Estagirita expõe como uma série de recursos pode ser utilizada em defesa de uma dada perspectiva, qualquer que seja, quer do acusador, quer do acusado. Por exemplo, em Retórica 1375a25-1375b25, Aristóteles elenca argumentos tanto pela admissão quanto pela rejeição da lei, caso ela seja favorável ou não à causa pleiteada. Dentre esses recursos, a prova testemunhal se destaca das demais por possibilitar ou superar ou aprofundar a dessimetria entre o éthos do acusador e do acusado, tendo como consequência a conformação do éthos das partes ( $R h$. 1376a24-33). Nesse sentido, levantar suspeitas sobre o éthos da parte adversa ( $R h$. 1416a4-1416b15) é uma estratégia que não pode ser descartada. Porém, a diabolé precisa estar de acordo com a técnica retórica, pois, do contrário, não passará de um simples expediente sofístico (Top. 100a18-101a24; Rh. 1354a12-26).

A distinção entre a diabolé, na Retórica, e a sofística se encontra no método. $\mathrm{O}$ argumento sofístico se caracteriza ou por fundamentar-se em premissas falsas ou por chegar a uma conclusão inválida $^{19}$ (Top. 100b23-26) usadas na intenção (prohaíresis) de

19 Angioni (2012) expõe bem essa distinção. No primeiro caso, as premissas têm
uma aparência de éndoxa, isto é, de serem proposições aceitáveis e/ou verdadeiras
de ou sobre algo, como "todas as aves voam" (há aves que não voam...) (ANGIONI,
2012 , p. 195-196). No segundo, a conclusão não segue as premissas, ou seja, é uma
falácia (ANGIONI, 2012, p. 191-194). Destaque-se que Angioni (2012, p. 197-198)
considera haver um terceiro tipo de argumento sofístico, qual seja, o embasado em
premissas válidas e que chega a uma conclusão igualmente válida, cuja pretensão 
conferir ao sofista a reputação de "sábio" (SE. 165a19-24). Por seu turno, enquanto um recurso retórico, a diabolé é elaborada com base em probabilidades, signos, exemplos e/ou lugares comuns ( $R h$. 1357a22-1358a35) desde o ponto de vista de um dado auditório (Rh. 1367b7-11; Rh. 1388b29-1391b7) sobre um determinado éthos (Rh. 1367a32-1367b26). Quer dizer, a sofística está no âmbito do objetivamente falso ao passo que a diabolé se insere na esfera do plausível, isto é, de como algo pode ser ainda que não o seja. Em outras palavras, a sofística falseia; a diabolé engana. ${ }^{20}$

Veja-se o exemplo dado por Aristóteles quando da exposição do parádeigma ( $R$ h. 1357b26-36). Não é porque Dionísio solicitou uma guarda pessoal que ele ambiciona a tirania, como o fizeram Pisístrato ou Teágenes. Mas, através das insinuações certas, é possível apor em Dionísio uma suspeita tal em seu caráter de modo a fazer com que se enxergue uma dada intenção, mesmo não sendo - ou seja, um engano plausível.

Ainda que não se possa desvincular a prova pelo éthos dos valores morais, é um desacerto considerá-la sob o viés da moralidade ou, pior, eleger uma moral enquanto um parâmetro de última instância. Tais valores são construídos socialmente e cada agrupamento social tem seu ponto de vista axiológico desde o qual define o moral, o imoral e o indiferente. Até Aristóteles, que tinha, e defendia, uma concepção moral sobre o éthos (EN. 1095a14-30), admitia a existência de outras cosmovisões ( $R h$. 1360b4-18), embora rejeitasse algumas delas (EN. 1095b14-1096a10).

Ciente dessas visões de Mundo e consciente de que a sua postura influencia a aceitação de seus argumentos ( $R h$. 1356a6-8), o rétor se porta, estrategicamente, de modo a se mostrar idôneo ( $R h$.

\footnotetext{
é apresentar como concludente uma explicação apenas parcial ou circunstancial de algo. Sobre a discussão desse terceiro tipo, cf. Angioni (2012, p. 198ss).

${ }^{20}$ Enquanto a falsidade se caracteriza por um erro ou uma mentira consciente sobre o algo do qual se fala, o engano está voltado para a pluralidade de perspectivas sobre esse algo (UNTERSTEINER, 2012, p. 173-183). Nesse sentido, a sofística procura fazer do falso o verdadeiro e a diabolé viabilizar certa feição de e/ou sobre algo como seu aspecto fenomenológico, mesmo que não o seja.
} 
1378a6-20) para aquele auditório (Rh. 1367b7-11). Assim, quer ressaltando seu próprio éthos, quer contrastando-o com o do seu adversário, ele destacará determinado aspecto do caráter, seja o seu, seja o do seu oponente, e apor-lhe-á um valor ( $R h$. 1367a321367b7) a fim de que seus argumentos se sobressaiam frente aos de seu adversário. Nesse sentido, não se pode descartar a diabolé enquanto uma ferramenta para tanto.

Dessa feita, em que pese os argumentos de Grimaldi, a leitura mais condizente com a retórica enquanto tékhnē é a de viés amoral. Se é certo que a retórica lida com valores e o próprio Aristóteles a vê como um ramo (paraphyés) da ética e da política ( $R h$. 1356a2527), também o é que os meios mais adequados para persuadir não se limitam aos meios morais, mas, sim, abrange todos aqueles aptos para persuadir, incluindo os "imorais" ( $R h$. 1355b26-27), o que a faz semelhante (homoîa) também à sofística ( $R h$. 1359b9-12). Assim, a retórica, por ser tékhnē - e a diabolé, enquanto um recurso seu -, é neutra quanto à moral (DAY, 2007, p. 389-391).

\section{Considerações finais}

Através da prova pelo éthos o orador se mostra alguém idôneo para um dado auditório e amplia a receptividade de seus argumentos. Não obstante, para Aristóteles, seu uso seja mais adequado nos discursos deliberativos ( $R h$. 1377b25-31), a prova pelo éthos desempenha um papel relevante no âmbito da retórica judicial, na qual, de antemão, há uma dessimetria entre o éthos do acusador e do acusado, uma circunstância superável ou intensificada se uma das partes se apresentar mais digna de crédito que a outra. Dentre as provas específicas da retórica judicial ( $R h$. 1375a22-25), os testemunhos são o meio adequado para o rétor denotar o valor de seu éthos em detrimento do de seu oponente, inclusive por meio da diabolé. Ainda que as interpretações de viés moral, cuja a leitura de Grimaldi é um exemplo significativo, procurem desvincular a retórica de expedientes considerados desonestos - alguns à beira da trapaça (Rh. 1401b3-9) -, a 
instrumentalidade da retórica aponta para seu amoralismo. No entanto, não basta levantar suspeitas: a suspeição precisa ser elaborada com técnica, a fim de não formular um argumento sofístico.

\section{Referências}

ANGIONI, Lucas. Três tipos de argumento sofístico. Pelotas, Dissertatio, v. 36, p. 187-220, 2012.

BARNES, Jonathan (ed.). The complete Works of Aristotle: the revised Oxford translation. Princeton: Princeton University Press, 1984. 2v.

BRUNSCHWIG, Jacques. Aristotle's rhetoric as a "counterpart" to dialectic. In: RORTY, Amélie Oksenberg (ed.). Essays on Aristotle's Rhetoric. Berkeley: University of California Press, 1996, p. 34-55.

COOPER, Craig. Forensic oratory. In: WORTHINGTON, Ian (ed.). $A$ Companion to Greek rhetoric. Oxford: Blackwell, 2007, p. 203-219.

DAY, Jane M. Rhetoric and Ethics from the Sophists to Aristotle. In: WORTHINGTON, Ian (ed.). A Companion to Greek rhetoric. Oxford: Blackwell, 2007, p. 378-392.

FORTENBAUGH, William W. Aristotle's accounts of persuasion through character. In: FORTENBAUGH, William W. Aristotle's practical side: on his psychology, ethics, politics and rhetoric. Leiden: Brill, 2006, p. 317-338.

GRIMALDI, SJ, William M. A. Aristotle, Rhetoric I: a commentary. New York: Fordham University Press, 1980.

GRIMALDI, SJ, William M. A. Aristotle, Rhetoric II: a commentary. New York: Fordham University Press, 1988.

GRIMALDI, SJ, William M. A. Studies in the philosophy of Aristotle's Rhetoric. Wiesbaden: Franz Steiner Verlag GMBH, 1972.

HUTCHINSON, Douglas S. Ethics. In: BARNES, Jonathan (ed.). The Cambridge Companion to Aristotle. Cambridge, UK: Cambridge University Press, 1999, p. 195-232.

ISÓCRATES. Ad Demonicus. In: NORLIN, George. Isocrates with an English Translation in three volumes. Cambridge, MA: Harvard University Press; London: William Heinemann, 1980. Disponível em: 
http://data.perseus.org /texts/urn:cts:greekLit:tlg0010.tlg007.perseuseng1. Acesso em: 22 de jan. 2020.

LIDDELL, Henry G.; SCOTT, Richard. A Greek-English lexicon (with a revised supplement). Rev. Henry S. James e Roderick McKenzie. Oxford: Clarendon Press, 1996.

SATTLER, William M. Conceptions of ethos in ancient rhetoric. Washington, Speech Monographs, v. 14, n. 1-2, 1947, p. 55-65.

UNTERSTEINER, Mario. A obra dos sofistas: uma interpretação filosófica. Tradução de Fernando Ambrósio. São Paulo: Paulus, 2012. 